CORRIGENDUM

\title{
Ionizing radiation modulates vascular endothelial growth factor (VEGF) expression through multiple mitogen activated protein kinase dependent pathways
}

Jong-Sung Park, Liang Qiao, Zao-Zong Su, Darin Hinman, Karen Willoughby, Robert McKinstry, Adly Yacoub, Gregory J Duigou, Charles SH Young, Steven Grant, Michael P Hagan, Earl Elliss, Paul B Fisher and Paul Dent

Correction to: Oncogene (2001) 20, 3266-3280.

Since publication of the above paper, the authors have identified two errors.

Firstly, the RT2 and T9 cell lines used in the manuscripts were originally obtained by Dr Martin R Graf (Department of Anatomy, Virginia Commonwealth University, Richmond, VA, USA) from Dr Yancey Gillespie (Department of Neurobiology, University of Alabama at Birmingham, AL, USA) and Dr Gale Granger (Department of Molecular Biology, University of California, Irvine, CA, USA) and not the American Tissue Type Culture Collection (ATTCC) as stated in the Methods section.

Secondly, in the Acknowledgments section, the authors neglected to acknowledge Dr Graf, the investigator who kindly supplied the unpublished information showing that $\mathrm{T} 9$ cells were less tumorigenic in vivo than RT2 cells. The authors would like to apologise to Dr Graf for this omission. 